\title{
Assessment of Knowledge and Attitudes of Teachers about Child Abuse in Selected Primary Schools at Minia City
}

\author{
Eman Mohamed Abd EL-Aziz', Yosria El-Sayed Hossein², Sabah Saleh Hassan ${ }^{3}$, Naglaa Mohammed Amein ${ }^{4}$
}

\author{
1. B.Sc. Nursing- Minia University, Egypt \\ 2. Professor of Community Health Nursing- Minia University, Egypt \\ 3. Lecturer of Psychiatric and Mental Health Nursing -Minia University, Egypt \\ 4. Lecturer of Community Health Nursing -Minia University, Egypt
}

\begin{abstract}
Background: Child abuse is one of the most important health issues worldwide, it continues to be one of primary threats to the child's emotional and social well-being globally. Aim of the study: is to assess the knowledge and attitude of the teachers about child abuse. Research design: A descriptive study design was used to conduct the study. Sample: Study was conducted on 274 school teachers. Setting: (8) urban and rural public primary school at Minia city. Tools of data collection: included two tools: First tool is an interviewing questionnaire comprised of two parts to assess socio demographic characteristics and knowledge of teachers regarding child abuse. Second tool the attitude is rating scale for Assessment of Teacher Attitude toward Child Abuse. Results: about two third of the school teachers had poor knowledge about child abuse and (62\%) had negative attitude about child abuse. Conclusion: Child abuse is a global issue and children face abuse in many forms and more awareness will help in combating the issues and problems with abuse. Recommendation: Design and implement an educational program for teachers to increase their awareness about child abuse and to promote child health.
\end{abstract}

Keywords: child abuse, knowledge, attitude, school teachers

\section{Introduction}

Childhood is a golden and enjoyable period of life so Protection of a child during this period is the responsibility of the professionals who care for the child. Beside the parents, teachers and physicians play a very important role. Child abuse and child neglect have negative psychological effect on children (Alsaleem et al., 2019). WHO define child abuse as "All types of physical and/or emotional illtreatment, sexual abuse, neglect, negligence and commercial or other exploitation, which results in actual or potential harm to the child's health, survival, development or dignity in the context of a relationship of responsibility, trust or power Exposure to intimate partner violence is also sometimes included as a form of child maltreatment" (WHO, 2014).

Child abuse continues to be one of the primary threats to the child's emotional and social well-being globally affects children of all ages, gender, races, ethnicities, in varied socio economic classes and is in the forefront in the line of widespread social issues and economic problems (Hynniewta et al., 2017). The World Health Organization (WHO) estimates that 40 million children aged below 15 years fall victim to violence each year. The ensuing traumas vary according to the gravity of the violence and the child's personal experience and can have medical and psychosocial consequences in the long run. (A jilian Abbasi et al., 2015)

Hynniewta, 2017 selected that Knowledge and attitudes of teachers influence the perception of abuse and consequently reporting cases. There are many factors that may potentially be influenced by their attitude and perception that may affect the quality of decision making and reporting of child abuse that teachers need to take into consideration. The lack of adequate knowledge and information indicate a gap in the crucial role of teachers in identification and early assistance of an abused child. (Hynniewta et al., 2017). In the same context (Choo, 2013) reported that Social and cultural values of communities may also influence the personal attitudes of teachers regarding what constitutes unacceptable behavior towards children and may affect their reporting

$P$ a g e | 56 behavior (Choo et al., 2013). Due to their coverage of children, primary school teachers and public child healthcare workers play a pivotal role in the prevention and identification of child abuse among children most at risk. To reduce the prevalence of child abuse and its related costs and human suffering, different preventive strategies can be used, from primary to secondary to tertiary prevention (Devore, 2013).

While preventing child abuse is recognized as a national and international priority, nurses are in a perfect position to intervene in child abuse and neglect at primary, secondary and tertiary levels as they interact with children in a variety of hospital- and community-based settings (Poreddi et al., 2016). The individual nurses must know their responsibilities and accept responsibility. Nurses have both an ethical and a legal responsibility towards maltreated children, which they cannot escape; this is at the ethical core of nursing care (Skarsaune et al., 2015).

All stakeholders, especially those in close contact with the child (for example teachers, doctors) need to be adequately trained to detect, manage and report any cases of maltreatment .If the child does not disclose the abuse, a teacher can detect abuse through observation of a child. This is the most likely situation to occur because of the stigma attached to child abuse. A child may be waiting for an adult to notice what's going on or may even be trying to hide the situation to protect a parent or guardian. Every child is different, which will cause each one to react differently to the abuse, but with each type of abuse there are some typical signs that a teacher would be able to notice (Wilson, 2012).

\section{Significance of the study:}

Children are suffering from a hidden epidemic of child abuse and neglect. It's a widespread war against our children that we have the power to stop, and understanding the issue is the first step. It is well known that the childhood period is the fundamental stages for providing children with knowledge and skills that enable them to face life and its

Eman M., et al 
requirements. So, the seriousness of child abuse phenomenon is that it has negative impact on children growth, development and personality which reflect negatively on the lives of child, family and society as a whole (National Center for Injury Prevention and Control, 2016)

School staff must be the first to become aware that a child may be a victim of abuse and is struggling because of adverse events occurring in his or her life (Feeser, 2017). Teachers are one of the important groups that in addition to teaching the students can have a role in control and identification of child maltreatment and violence in schools (Boroumandfar et al., 2015). Add to that, various researches findings that teachers are lacking in the areas of specific knowledge and attitude regarding child abuse that required effective guidance and supportive direction in relation to early detection and reporting of cases so different preventive strategies can be taken ( Hynniewta et al., 2017).

\section{Aim of this study:}

To assess the knowledge and attitudes of teachers about child abuse in selected primary schools at Minia city.

\section{Research Questions:}

1. what is level of teacher's knowledge about child abuse?

2. What are the teacher attitudes about child abuse?

3 . Is there relation between teacher knowledge and attitudes regarding child abuse and socio-demographic characteristics of the teachers?

\section{Research design:}

A descriptive design was used in this study.

\section{Setting:}

The study was conducted in (8) urban and rural public primary schools at Minia city included : 6 October, Taha Hussein, El Shaheed, Kafr El Mansoura, El sheik Essa, Damshir 1, Tala Girls 2 and Al Borgaya Boys2.

\section{Sampling:}

Previous schools sample selected by using multistage sample. A purposive sample of 274 teachers was selected, which represented all male and female teachers who have equal or more than five years of experience working in eight pre mentioned urban and rural primary schools. The study of sample 145 from urban schools and 129 from rural schools distributed as follows: 25 from 6 October school, 27 from Taha Hussein school, 42 from El Shaheed school, 51 from Kafr El Mansoura school, 34 from El sheik Essa, 25 from Damshir 1school, 32 from Tala Girls 2 School and 38 from Al Borgaya Boys School.

\section{Tools of The Study:} include:

Two tools were used to collect the necessary data

\section{First Tool:}

An interviewing questionnaire: It was developed by the investigator based on reviewing the related literatures and considering the experts opinions, it comprised of two parts to assess the following:

\section{Part 1:}

Socio demographic characteristics includes: $(\wedge)$ questions such as (age, gender, marital status, place of residence, educational level, monthly income, number of children, years of experience)

\section{Part 2:}

Knowledge of teachers regarding child abuse includes: question about (types of abuse, Signs of physical abuse, behavioral signs of physical abuse, types of emotional abuse, ... etc).

Scoring system each correct answer scored as one point and each incorrect answer scored as zero. The total score for all question related to knowledge was 103 point (100\%), and categorized into three level as following:

- Poor $(0-<60 \%)$

- Average $(\geq 60-74 \%)$

- Good $(\geq 75 \%)$

Second Tool: It was developed by (Mekheimar, 2011) an Attitude Rating Scale for assessment of teacher attitude toward Child Abuse: it was modified by jury, it composed of 23 items using rating scale of two level (agree, and disagree)

The score ranged from one to two, disagree $=1$, agree $=2$, total score of the scale equal 46 points, which represents $100 \%$.

- $\quad$ Positive attitude $\geq 24$ degree $50 \%$

- $\quad$ Negative attitude $\leq 22$ degree $50 \%$

\section{Validity:}

To establish validity, the questionnaire was piloted on panel of five experts of community nursing staff, who was reviewed the instruments for clarity, relevance comprehensiveness, understanding, applicability and easiness.

\section{Reliability}

The internal consistency of the questionnaire was calculated using cronbach's alpha coefficient, test retest was used. The cronbach's alpha it was alpha of the questionnaire were 0.509 and 0.741 respectively.

\section{Pilot study:}

Pilot study was conducted on $10 \%$ from the total number of study which equal 30 teachers to test the study process and to evaluate the efficiency and clarity of tools that were used in the study. It also was help in the estimation of the time needed to fill the form.

\section{Ethical Consideration:}

Approval was sought from the provincial and district ethical committee befor under taking the research. Written informed consent was obtained from each participating teachers after explaining the nature and benefits of the study. The participant was informed that their participation in the study was completely voluntary and there was no harm if they not participate in the study. Privacy was considered during collection of data. Participants was assure that all their data are highly confidential

\section{Study Procedure:}

An official letter of the study approval was obtained from the dean of the faculty of nursing at Minia University to the Directorate of Education and the request was transferred to primary education and one school was selected from each sector in mina city to carry out the study. This letter was included brief explanation of the aim of the study and permission was requested from each manager to carry out the 
study. Data was collected two days per week; Data was collected on Sunday and Monday per week at school time. It was lasted for three months years of 2018; the interviewers explained the questions of the questionnaire to the teachers. Tools were introduced to teachers to be filled and each interview consisted of five teachers and last for half an hour, ten minute to explain the questionnaire and a third of an hour to fill out the questionnaire
Data statistical analysis:

Data were collected tabulated and analyzed by computer using" the statistical package for social science "(SPSS) version 20, descriptive data were expressed as number and percentage. Questionnaire data were presented by mean and standard deviation. Correlation was calculated between knowledge and attitude about child abuse using person correlation test. Probability ( $\mathrm{p}$-value) Equal to or less than 0.05 was considered significant in test of relationships.

\section{Results}

Table (1): Distribution of the studying teachers according to their demographic characters (No- 274)

\begin{tabular}{|c|c|c|c|c|c|c|c|}
\hline \multirow[t]{2}{*}{ Data } & \multicolumn{2}{|c|}{$\begin{array}{l}\text { Total } \\
\text { n-274 }\end{array}$} & \multicolumn{2}{|c|}{$\begin{array}{c}\text { Urban school } \\
n-145\end{array}$} & \multicolumn{2}{|c|}{$\begin{array}{c}\text { Rural School } \\
\text { n-129 }\end{array}$} & \multirow[t]{2}{*}{$\mathrm{p}$} \\
\hline & No. & $\%$ & No. & $\%$ & No. & $\%$ & \\
\hline $\begin{array}{l}\text { Age Range } \\
\text { Mean } \pm \text { SD }\end{array}$ & \multicolumn{2}{|c|}{$\begin{array}{c}27-58 \\
39 \pm 6.8\end{array}$} & \multicolumn{2}{|c|}{$\begin{array}{c}27-57 \\
40.1 \pm 6.9\end{array}$} & \multicolumn{2}{|c|}{$\begin{array}{c}28-58 \\
37.7 \pm 6.6\end{array}$} & $0.008 *$ \\
\hline \multicolumn{8}{|l|}{ Gender } \\
\hline Male & 121 & $(44.2 \%)$ & 75 & $(51.7 \%)$ & 46 & $(35.7 \%)$ & \multirow{2}{*}{$0.008 *$} \\
\hline Female & 153 & $(55.8 \%)$ & 70 & $(48.3 \%)$ & 83 & $(64.3 \%)$ & \\
\hline \multicolumn{7}{|c|}{ Marital status } & \multirow{5}{*}{0.2} \\
\hline Single & 21 & $(7.7 \%)$ & 15 & $(10.3 \%)$ & 6 & $(4.7 \%)$ & \\
\hline Married & 231 & $(84.3 \%)$ & 117 & $(80.7 \%)$ & 114 & $(88.4 \%)$ & \\
\hline Divorced & 13 & $(4.7 \%)$ & 8 & $(5.5 \%)$ & 5 & $(3.9 \%)$ & \\
\hline Widow & 9 & $(3.3 \%)$ & 5 & $(3.4 \%)$ & 4 & $(3.1 \%)$ & \\
\hline \multicolumn{7}{|l|}{ Residence } & \multirow{3}{*}{$0.001 *$} \\
\hline Urban & 172 & $(62.8 \%)$ & 124 & $(85.5 \%)$ & 48 & $(37.2 \%)$ & \\
\hline Rural & 102 & $(37.2 \%)$ & 21 & $(14.5 \%)$ & 81 & $(62.8 \%)$ & \\
\hline \multicolumn{7}{|l|}{ Income } & \multirow{3}{*}{0.4} \\
\hline In Sufficient & 141 & $(51.5 \%)$ & 78 & $(53.8 \%)$ & 63 & $(48.8 \%)$ & \\
\hline Sufficient & 133 & $(48.5 \%)$ & 67 & $(46.2 \%)$ & 66 & $(51.2 \%)$ & \\
\hline \multicolumn{7}{|c|}{ Number of child } & \multirow{4}{*}{0.1} \\
\hline No & 0. & $(1 \wedge . \curlyvee \%)$ & 31 & $(21.4 \%)$ & 19 & $(14 . \vee \%)$ & \\
\hline $1-3$ & 133 & $(48.7 \%)$ & 73 & $(50.3 \%)$ & 60 & $(46.9 \%)$ & \\
\hline$>3$ & 91 & $(33.3 \%)$ & 41 & $(28.3 \%)$ & 50 & $(39.1 \%)$ & \\
\hline \multicolumn{7}{|c|}{ Years of experience } & \multirow{4}{*}{0.6} \\
\hline $5-<10$ & 118 & $(43.1 \%)$ & 59 & $(40.7 \%)$ & 59 & $(45.7 \%)$ & \\
\hline $10-<20$ & 85 & $(31 \%)$ & 48 & $(33.1 \%)$ & 37 & $(28.7 \%)$ & \\
\hline$\geq 20$ & 71 & $(25.9 \%)$ & 38 & $(26.2 \%)$ & 33 & $(25.6 \%)$ & \\
\hline \multicolumn{7}{|c|}{ Educational level } & \multirow{3}{*}{$0.004 *$} \\
\hline Secondary & 54 & $(19.7 \%)$ & 38 & $(26.2 \%)$ & 16 & $(12.4 \%)$ & \\
\hline University & 220 & $(80.3 \%)$ & 107 & $(73.8 \%)$ & 113 & $(87.6 \%)$ & \\
\hline
\end{tabular}

Table(1): Illustrating that their age is ranged from $27-58$ with a mean of $39 \pm 6.8$. As well as more half of gender were females, also $62.8 \%$ of total teacher residences in urban area, as well as $80.3 \%$ of total teachers were university education. In addition there are statistically significant differences between rural and urban schools in age, gender, residence and educational level at $\mathrm{p}$ value $(0.008,0.008,0.001,0.004)$ respectively.

Table (2): Teachers knowledge about notification of child abuse (No- 274)

\begin{tabular}{|c|c|c|c|c|c|c|c|}
\hline Notification & \multicolumn{2}{|c|}{$\begin{array}{l}\text { Total } \\
\text { n-274 } \\
\end{array}$} & \multicolumn{2}{|c|}{$\begin{array}{c}\text { Urban school } \\
\text { n-145 }\end{array}$} & \multicolumn{2}{|c|}{$\begin{array}{c}\text { Rural School } \\
\text { n-129 }\end{array}$} & $\mathrm{p}$ \\
\hline & No & $\%$ & No & $\%$ & No & $\%$ & \multirow{9}{*}{$0.01 *$} \\
\hline Psychiatrist & 89 & $(32.5) \%$ & 48 & $(33.1 \%)$ & 41 & $(31.8 \%)$ & \\
\hline Social & 82 & $(29.9) \%$ & 41 & $(28.3 \%)$ & 41 & $(31.8 \%)$ & \\
\hline nurse & 7 & $(2.6) \%$ & 3 & $(2.1 \%)$ & 4 & $(3.1 \%)$ & \\
\hline Manager & 12 & $(4.4) \%$ & 9 & $(6.2 \%)$ & 3 & $(2.3 \%)$ & \\
\hline Police & 9 & $(3.3) \%$ & 7 & $(4.8 \%)$ & 2 & $(1.6 \%)$ & \\
\hline Committee & 3 & $(1.1 \%)$ & 3 & $(2.1 \%)$ & 0 & $(0.0 \%)$ & \\
\hline Parents & 10 & $(3.6 \%)$ & 9 & $(6.2 \%)$ & 1 & $(0.8 \%)$ & \\
\hline Don't know & 62 & $(22.6 \%)$ & 25 & $(17.2 \%)$ & 37 & $(28.7 \%)$ & \\
\hline
\end{tabular}

Table (2) showing that $32.5 \%$ of teachers say notification of child abuse to psychiatric moreover there is statistically significant difference between urban and rural school teacher. 
P V $=0.6$

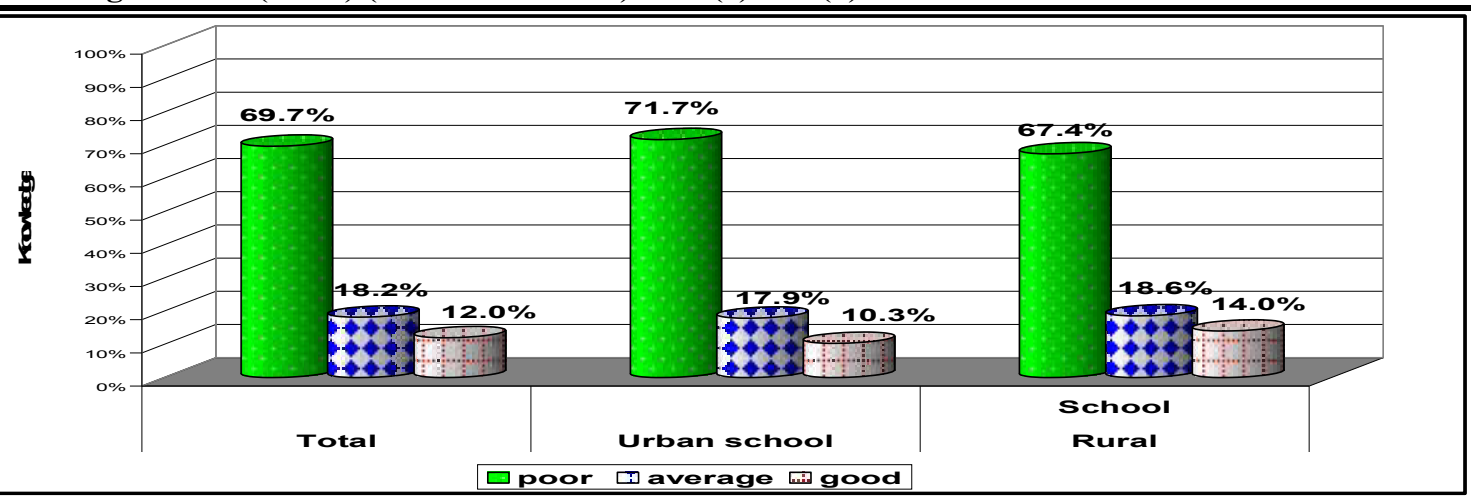

Figure 1 knowledge of teachers about child abuse

Figure (1): Showing that more than two third of teachers had poor knowledge about child abuse

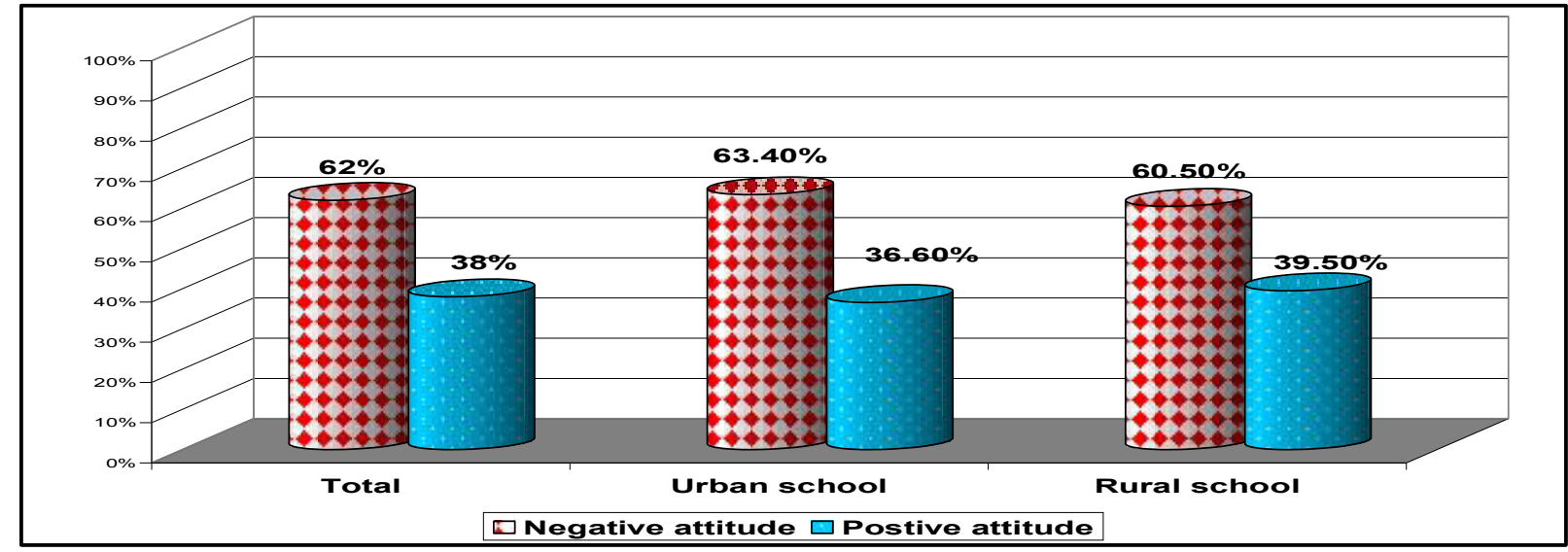

Figure 2 Attitude of teachers regarding child abuse

$P \mathrm{~V}=0.6$

Figure (2): Showing that $62 \%$ of teachers had negative attitude regarding child abuse

Table (3): Relation socio demographic characters of teachers and their knowledge about child abuse (No- 274).

\begin{tabular}{|c|c|c|c|c|c|c|c|}
\hline \multirow{4}{*}{$\begin{array}{l}\text { Data } \\
\\
\text { Age Mean } \pm \text { SD } \\
\text { Gender }\end{array}$} & \multicolumn{2}{|c|}{$\begin{array}{c}\text { Poor knowledge } \\
\text { n-191 }\end{array}$} & \multicolumn{2}{|c|}{$\begin{array}{c}\text { Average knowledge } \\
\text { n-50 }\end{array}$} & \multicolumn{2}{|c|}{$\begin{array}{c}\text { Good knowledge } \\
\text { n-33 }\end{array}$} & \multirow[t]{2}{*}{$\mathbf{p}$} \\
\hline & No. & $\%$ & No. & $\%$ & No & $\%$ & \\
\hline & \multicolumn{2}{|c|}{$38.7 \pm 6.8$} & \multicolumn{2}{|c|}{$39.9 \pm 6.9$} & \multicolumn{2}{|c|}{$38.7 \pm 6.6$} & \multirow{2}{*}{0.5} \\
\hline & & & & & & & \\
\hline Male & 84 & $(44 \%)$ & 24 & $(48 \%)$ & 13 & $(39.4 \%)$ & \multirow{2}{*}{0.7} \\
\hline Female & 107 & $(56 \%)$ & 26 & $(52 \%)$ & 20 & $(60.6 \%)$ & \\
\hline \multicolumn{7}{|l|}{ Marital status } & \multirow{5}{*}{0.9} \\
\hline Single & 16 & $(8.4 \%)$ & 4 & $(8 \%)$ & 1 & $(3 \%)$ & \\
\hline Married & 159 & $(83.2 \%)$ & 42 & $(84 \%)$ & 30 & $(90.9 \%)$ & \\
\hline Divorced & 10 & $(5.2 \%)$ & 2 & $(4 \%)$ & 1 & $(3 \%)$ & \\
\hline Widow & 6 & $(3.1 \%)$ & 2 & $(4 \%)$ & 1 & $(3 \%)$ & \\
\hline \multicolumn{7}{|l|}{ Residence } & \multirow{4}{*}{0.9} \\
\hline Urban & 120 & $(62.8 \%)$ & 31 & $(62 \%)$ & 21 & $(63.6 \%)$ & \\
\hline Rural & 71 & $(37.2 \%)$ & 19 & $(38 \%)$ & 12 & $(36.4 \%)$ & \\
\hline \multicolumn{7}{|l|}{ Income } & \\
\hline In Sufficient & 94 & $(49.2 \%)$ & 27 & $(54 \%)$ & 20 & $(60.6 \%)$ & \multirow{3}{*}{0.4} \\
\hline Sufficient & 97 & $(50.8 \%)$ & 23 & $(46 \%)$ & 13 & $(39.4 \%)$ & \\
\hline \multicolumn{7}{|l|}{ Number of child } & \\
\hline No & 40 & $(20.4 \%)$ & 8 & $(16 \%)$ & 3 & $(9.1 \%)$ & \multirow{3}{*}{0.4} \\
\hline $1-3$ & 90 & $(47.4 \%)$ & 27 & $(54 \%)$ & 16 & $(48.5 \%)$ & \\
\hline$>3$ & 62 & $(32.6 \%)$ & 15 & $(30 \%)$ & 14 & $(42.4 \%)$ & \\
\hline \multicolumn{7}{|c|}{ Years of experience } & \multirow{4}{*}{$0.001 *$} \\
\hline $5-<10$ & 104 & $(54.4 \%)$ & 14 & $(28 \%)$ & 0 & 0 & \\
\hline $10-<20$ & 57 & $(29.8 \%)$ & 15 & $(30 \%)$ & 13 & $(39.4 \%)$ & \\
\hline$\geq 20$ & 30 & $(15.7 \%)$ & 21 & $(42 \%)$ & 20 & $(60.6 \%)$ & \\
\hline \multicolumn{7}{|l|}{ Educational level } & \multirow{3}{*}{$0.006^{*}$} \\
\hline Secondary & 45 & $(23.5 \%)$ & 9 & $(18 \%)$ & 0 & 0 & \\
\hline University & 146 & $(76.4 \%)$ & 41 & $(82 \%)$ & 33 & $(100 \%)$ & \\
\hline
\end{tabular}

Table (3): Illustrating that present $60.6 \%$ of teachers who their experience more than 20 years of teachers who have good knowledge about child abuse. As well as $100 \%$ of teachers with university education of teachers who have good knowledge. In addition, there are statistically significant differences between years of experience and educational level with their knowledge at $\mathrm{p}$ value $(0.001,0.006)$ respectively. 
Table (4): Relation socio demographic characters of teachers and their attitude about child abuse (No- 274).

\begin{tabular}{|c|c|c|c|c|c|}
\hline \multirow[t]{2}{*}{ Data } & \multicolumn{2}{|c|}{$\begin{array}{c}\text { Negative attitude } \\
n-170\end{array}$} & \multicolumn{2}{|c|}{$\begin{array}{c}\text { Positive attitude } \\
\text { n-104 }\end{array}$} & \multirow[t]{2}{*}{$\mathbf{p}$} \\
\hline & No. & $\%$ & No. & $\%$ & \\
\hline Age Mean \pm SD & $37.9 \pm 6.4$ & & & $40.7 \pm 7.2$ & $0.001^{*}$ \\
\hline \multicolumn{6}{|l|}{ Gender } \\
\hline Male & 79 & $(46.5 \%)$ & 42 & $(40.4 \%)$ & 0.3 \\
\hline Female & 91 & $(53.5 \%)$ & 62 & $(56.6 \%)$ & \\
\hline \multicolumn{6}{|l|}{ Marital status } \\
\hline Single & 15 & $(8.8 \%)$ & 6 & $(5.8 \%)$ & $0.004 *$ \\
\hline Married & 143 & $(84.1 \%)$ & 88 & $(84.6 \%)$ & \\
\hline Divorced & 11 & $(6.5 \%)$ & 2 & $(1.4 \%)$ & \\
\hline Widow & 1 & $(0.6 \%)$ & 8 & $(7.7 \%)$ & \\
\hline \multicolumn{6}{|l|}{ Residence } \\
\hline Urban & 115 & $(67.6 \%)$ & 57 & $(54.8 \%)$ & $0.03 *$ \\
\hline Rural & 55 & $(32.4 \%)$ & 47 & $(45.2 \%)$ & \\
\hline \multicolumn{6}{|l|}{ Income } \\
\hline In sufficient & 87 & $(51.2 \%)$ & 54 & $(51.9 \%)$ & 0.9 \\
\hline Sufficient & 83 & $(48.8 \%)$ & 50 & $(48.1 \%)$ & \\
\hline \multicolumn{6}{|l|}{ Number of child } \\
\hline No & 31 & $(18.2 \%)$ & 18 & $(17.5 \%)$ & 0.4 \\
\hline $1-3$ & 87 & $(51.2 \%)$ & 46 & $(44.7 \%)$ & \\
\hline$>3$ & 52 & $(30.6 \%)$ & 39 & $(37.9 \%)$ & \\
\hline \multicolumn{6}{|c|}{ Years of experience } \\
\hline $5-<10$ & 84 & $(49.4 \%)$ & 34 & $(32.7 \%)$ & $0.01 *$ \\
\hline $10-<20$ & 25 & $(25.9 \%)$ & 41 & $(39.4 \%)$ & \\
\hline$\geq 20$ & 42 & $(24.7 \%)$ & 29 & $(27.9 \%)$ & \\
\hline \multicolumn{6}{|c|}{ Educational level } \\
\hline Secondary & 40 & $(23.5 \%)$ & 14 & $(13.5 \%)$ & $0.04 *$ \\
\hline University & 130 & $(76.5 \%)$ & 90 & $(86.5 \%)$ & \\
\hline
\end{tabular}

Table(4): Illustrating that present teachers with age mean \pm SD $40.7 \pm 7.2$ have positive attitude, as well as $84.6 \%$ of teachers who have positive attitude from married teachers, also $67.6 \%$ of teachers who have negative attitude from teachers urban area, $49.4 \%$ of teachers who have negative attitude whose years of experience $5-<10$ and $86.5 \%$ who had positive attitude from university education. In addition there are statistically highly significance differences between marital status, residence, years of experience as well as educational level at $\mathrm{p}$ value $(0.001,0.004,0.03,0.01,0.04)$ respectively.

\section{Discussion}

"Children are still the fruit of the marital relationship". Every day, millions of children throughout the world are subjected to abuse, neglect, exploitation and violence in different settings, including in their homes, schools, communities and work environments. As a result, children experience impacts on their physical and mental health, their education and their overall quality of life. The consequences of violence on children are often intergenerational, with those who have faced violence as a child more likely to become a violent adult. This cycle has a long-term impact on a family's economic wellbeing (Pereznieto et al., 2014).

In the current study, regarding the socio-demographic data of the teachers noted that age of total teachers ranged from 27-58 years. This is not consistent with study by (Naregal, 201') which showed that $43.33 \%$ belongs to the age group of below 25 years. Numbers of female teachers were more than half this may be due to that female prefer to work in the field of education. This is consistent with study by (Hynniewta et al., 2017) which showed that majority $(89 \%)$ were females due to female tendencies to teach more than males, study by (Sahebihagh et al., 2016) showed that $(81.9 \%)$ were females and study by (Naregal, 2017) showed that $(90 \%)$ primary school teachers were female.

Although in this study about two third of rural teachers were female it may explained by that the rural people prefer female work in the field of education. Also current study showed that the number of teachers from urban area more than rural area because of increasing in the density of urban schools and most prefer to stay in cities to improve living conditions.as well as $(80.3 \%)$ of total teachers were university education this is due to secondary education of five years not present now and replace it with university education also study by (Sahebihagh et al., 2016) showed that (60.6\%) were Bachelor's Degree or Higher.

The current study showed that about one third of teachers said notification of child abuse to Psychiatric may be the most people can deal with this problem. As well as nearly one quarter of urban and rural teachers they do not know how to communicate effectively and contact with psychologist and social work this due to lack of contact with other elements but not present solve of problem. Also (Preidt, 2011) stated that the reporting of child abuse cases among primary care providers showed that $(21 \%)$ of suspected cases were not reported. Moreover, (Eads, 2013) concluded that "Underreporting child abuse has become an epidemic.

The current study illustrated that more than two third of teachers had poor knowledge about child abuse may be due to lack of educational programmers for teachers about child abuse. this consistent with study by (Naregal, 2017) which showed that in pre-test majority $(60 \%)$ teachers had poor and $(20 \%)$ had average and good knowledge regarding child abuse and neglect respectively also in a study by (Mekhamier, 2011)revealed that the majority of the primary school teachers had poor knowledge score levels related to child abuse. Also the previous findings this inconsistent with study by (Hynniewta et al., 2017) which showed that (80\%) of the subjects had average knowledge on child abuse.

Although in study by (Schols et al., 2013) that conducted at Netherland to investigate Dutch frontline 
workers' child abuse detection and reporting behaviors. Focus group interviews were held among 16 primary school teachers and 17 public health nurses and physicians. Findings showed that teachers were experiencing a lack of knowledge of signs of abuse, baseline rates of abuse, and child abuse reporting procedures. Some teachers expressed that they would like to gain more knowledge in the areas of child neglect and child emotional abuse study concludes that frontline workers are in need of supportive tools in the child abuse detection and reporting process.

Regarding to teachers attitude about child abuse this study result showed that nearly two third of teachers have negative attitude toward child abuse this may due to lack of knowledge and awareness of the signs of child abuse and reporting procedures, which may affect their ability to report cases of suspected abuse. Future studies should further explore sociocultural and sociopolitical influences on attitudes (via characteristics such as views on adherence to family roles, conformity to norms, perceptions of punishment, and conceptions of shame, self-reliance, and spirituality).this is consistent with results of (Mekhamier, 2011) which demonstrated that the majority of primary school teachers had negative attitude towards child abuse among rural primary schools. Whereas this is not consistent with result of (Hynniewta et al., 2017) All the teachers (100\%) had favourable attitude towards identification and reporting of child abuse. and not consistent with result of (Sahebihagh et al., 2016) which showed that (95\%) of the teachers had favorable attitude it could attributed to cultural differences.

The study result demonstrated that there were statistically significant difference between socio demographic characters of teachers and their knowledge, in which $60.6 \%$ of teachers from 20 years of experience had good knowledge about child abuse this may be due to increase of experience about how to deal with child. This consistent with study by (Mekhamier, 2011) in which showed that there is statistical significant difference between teachers teaching experience and their knowledge.

Also there were statistically significant difference between teachers educational level and their knowledge this study showed that all teachers with good knowledge were university education and largest percentage of secondary education represented in poor knowledge this may due to The difference of generations in some concepts of education and methods of punishment also may be program in social media play important role in enhance community awareness about child abuse in recent time. Also this consistent with study by (Mekhamier, 2011) which showed that there is statistical significant difference between total knowledge score levels of the study sample and their level of education.

Although there is no statistical significant differences between primary school teachers age, gender, marital status, income, and number of their children and their total knowledge score levels. This finding is consistent with the study finding by previous author in which there is no statistical significant differences between Primary school teachers age, gender, marital status, income, and number of their children and their total knowledge score levels this is may be due to similarity of culture. Also it consistent with study of (Hynniewta et al., 2017) no significant association was found between knowledge and the selected demographic variables such as age, gender, marital status, education, and years of experience.
The current study revealed that relation of teachers attitude about child abuse teachers with negative attitude were of younger age it may be due to lack of knowledge how to deal with children and solve their problem.in this study the majority who had positive attitude from married teachers may be due to increase of experience in how to deal with child, also about two third who have negative attitude of teachers from urban residence this may be due to increase life stress in urban community, about half were lower experience due to lack of awareness about problem related to child and how to solve it. The majority who had positive attitude have university education due to increase level of knowledge in their university study. This findings consistent with (Mekhamier, 2011) findings revealed that there is highly statistical significant difference between primary school teacher's age, teaching experience and level of education and their attitude. Also it is inconsistent with (Hynniewta et al., 2017) who founded that all the teachers had favorable attitude, no association was found out between attitude and the selected demographic variable.

\section{Conclusion}

Based on the findings of the present study it can conclude that about two third of the school teachers had poor knowledge about child abuse and (62\%) had negative attitude about child abuse.

\section{Recommendations}

From the previous findings the following recommendation is suggested Conduct further researches to investigate the contributory factors leading to child abuse and the adequate intervention.

\section{References}

1) A jilian Abbasi, M., Saeidi, M., Khademi, G., Hoseini, B, \& Emami Moghadam, Z. (2015). Child Maltreatment in the World: A Review Article. International Journal of Pediatrics, 3(1.1), 353-365.)

2) Alsaleem, S., Alsaleem, M., Asiri, A., Alkhidhran, S., Alqahtani, W. S., Alzahrani, M, ... \& Alsamghan, A. (2019). Knowledge and attitude regarding child abuse among primary health care physician in Abha, Saudi Arabia, 2018. Journal of Family Medicine and Primary Care, 8(2), 706)

3) Boroumandfar, Z., Kohan, S., Mohaghegh, N., Mohammadirizi, S., \& Hassanzadeh, A. (2015) The Prevalence and Types of Child Abuse among Teachers and its Relationship with their Demographic Characteristics and General Health in Primary Schools. International Journal of Pediatrics, 3(4)., 853-859.

4) Choo, W., Walsh, K., Chinna, K., \& Tey, N. (2013). Teacher reporting attitudes scale (TRAS) confirmatory and exploratory factor analyses with a Malaysian sample. Journal of interpersonal violence, 28(2), 231-253.

5) Devore CD, Wheeler LS; (2013) role of the school physician. Pediatrics. ;131(1):178-182

6) Eads K. Breaking silence: Underreported child abuse in the healthcare setting. Online Journal of Health Ethics 2013;9. http://dx.doi.org/10.18785/ojhe. 0901.01. 
7) Feeser, C. (2017) care of victims of child maltreatment:the school nurses role by national association school nurses Available from https://schoolnursenet.nasn.org/blogs/nasn

8) Hynniewta, B., Jose, T., \& Anjali, K.. (2017). Knowledge and attitude on child abuse among school teachers in selected urban English medium schools of Udupi District. Manipal Journal of Nursing and Health Sciences, 3(1), 32-36.

9) Mekheimar, H. A.(2011).Teachers Perception regarding Abuse of Rural Primary Schools Children in Dakahlia Governorate, Ain Shams University

10) Naregal,p.m (2016) effectiveness of planned teaching programme on knowledge regarding prevention of child abuse and neglect among primary school teachers.online journal of health and allied science $14(4)$

11) National center for injury prevention and control, division of violence prevention . Adverse Childhood Experiences . April (2016). Available from: https://www.cdc.gov/violenceprevention/acestudy/\#1

12) Pereznieto, P., Montes, A., Routier, S., \& Langston, L. (2014) the costs and economic impact of violence against children. Richmond, VA: ChildFund

13) poreddi, V., Pashapu, D., Kathyayani, B., Gandhi, S., El-Arousy, W., \& Math, S. (2016). Nursing students' knowledge of child abuse and neglect in India. British journal of nursing, 25(5), 264-268.
14) Preidt R. Why some medical practitioners underreport child abuse. Health Day News 2011. Available

from: http://www.babycenter.com/204_whysomemedical-practitionersunderreport-childabuse 10359618.bc.

15) Sahebihagh, M., Hosseini, S., Hosseinzadeh, M., \& Shamshirgaran, S.. (2016). Knowledge, Attitude, and Practice of Teachers in Tabriz (Iran) Elementry Schools Regarding Child Abuse (20152016). international journal of medical research \& health sciences, 5(9), 336-343

16) Schols MWA, de Ruiter C, Ory FG. How do public child healthcare professionals and primary school teachers identify and handle child abuse cases? A qualitative study; BMC Public Health. 2013;13:807

17) Skarsaune, K., \& Bondas, T. (2015). Neglected nursing responsibility when suspecting child abuse violence, 28(2), 231-253.

18) Wilson, A. (2012). Life or Death: The Relationship Between Child Abuse and the Education System.

19) World Health Organization (WHO). Child maltreatment. Geneva: WHO; 2014. Available at: http://www.who.int/mediacentre/factsheets/fs 150/en/. [assessed 1/11/2014]. 